\title{
Engineering Good: How Engineering Metaphors Help us to Understand the Moral Life and Change Society
}

\author{
Mark Coeckelbergh
}

Received: 15 April 2009/Accepted: 14 August 2009/Published online: 1 September 2009

(C) The Author(s) 2009. This article is published with open access at Springerlink.com

\begin{abstract}
Engineering can learn from ethics, but ethics can also learn from engineering. In this paper, I discuss what engineering metaphors can teach us about practical philosophy. Using metaphors such as calculation, performance, and open source, I articulate two opposing views of morality and politics: one that relies on images related to engineering as science and one that draws on images of engineering practice. I argue that the latter view and its metaphors provide a more adequate way to understand and guide the moral life. Responding to two problems of alienation and taking into account developments such as Fab Lab I then further explore the implications of this view for engineering and society.
\end{abstract}

Keywords Metaphor $\cdot$ Morality $\cdot$ Engineering $\cdot$ Politics $\cdot$ Alienation · Open source $\cdot$ Fab Lab

\section{Introduction}

Usually engineering ethics is concerned with the application of ethical theory to engineering. In this paper, I make a move in the opposite direction: I explore what practical philosophy can learn from engineering. In particular, I discuss what engineering metaphors can teach us about morality and politics. Then I discuss the implications for engineering. In this way I show how engineering and philosophy can learn from one another.

Of course, engineering is itself a morally relevant activity: artefacts have moral consequences (see for instance Verbeek 2005) and is sometimes driven by a moral

\footnotetext{
M. Coeckelbergh ( $\bowtie)$

Department of Philosophy, University of Twente, P.O. Box 217, 7500 AE Enschede,

The Netherlands

e-mail: m.coeckelbergh@utwente.nl
} 
ideal when it attempts to make the world a better place. But my aim is different here: I show that there are some formal, structural features of engineering practice which, by means of metaphorical transfer to ethics and political philosophy, can help us to better understand normative philosophical inquiry and reconceptualise its agenda.

Using engineering metaphors, I will articulate two opposing views of morality and politics. The first relies on metaphors related to engineering as a science and a top-down activity; the second draws on metaphors related to engineering as a practice that develops bottom-up. I will argue that the latter view and its metaphors provide a more adequate way to understand and guide the moral life. Then I will explore the implications of this view for engineering design, production, and consumption by responding to two alienation problems in contemporary society.

Let me first make explicit my view of the relation between metaphor and moral thinking.

\section{Metaphor and Moral Thinking}

There are at least three views of the relation between metaphors and thinking, including moral thinking. On the first view, metaphors are means that help us to express thoughts in a more smooth and pleasant manner. They are decorations that add rhetorical value to our arguments. On the second view, this decorative position puts metaphors in a too positive light. Rather than aids, metaphors are unwelcome additions that distract from the purity of clear language. The third view rejects both instrumental conceptions of the relation between metaphors and thinking. It holds that metaphors are crucial and central to thinking itself. They are not the cloths that conceal the beauty of the propositional body; they are the backbone of reflection. They are not the paint; they are the building blocks of thinking. This is the view I shall assume in this paper. ${ }^{1}$

In moral philosophy, the latter position has been mainly (but not exclusively) developed by philosophers from the pragmatist tradition. In their classic work Metaphors We Live By (1980) Lakoff and Johnson have shown that metaphors are fundamental to thinking. Johnson (1993) has worked out the implications of this insight for ethics and Fesmire (2003) has used metaphors such as jazz improvisation to elaborate a Deweyan view of ethics.

Making explicit metaphors, then, serves the descriptive and normative aims of practical philosophy. It helps to articulate and clarify several existing frameworks for understanding morality and politics, but to the extent that these existing frameworks are inadequate it also helps us to imagine alternatives or improvements. My articulation and use of engineering metaphors in this paper is meant to contribute to both aims.

\footnotetext{
1 Note that for the purposes of the arguments made in this paper one could also assume a slightly 'weaker' version of this 'strong' view about the primacy of metaphor, as long as that version does not come too close to what I called the 'decorative' view.
} 


\section{Morality as (Theoretical) Science and Top-Down Politics}

Engineering is often conceived of as a science. Sciences provide a clear and fixed method to reach their aim. The aim of science is knowledge. For instance, engineers working in an academic context may aim to gain more knowledge about fluid dynamics, and build things that help them to reach that aim. Similarly, moral philosophy can understand itself as a science that aims to gain knowledge about moral values and moral reasoning. It may also become epistemology or philosophy of science and think about the justification of knowledge.

Within such a scientific approach to morality, moral philosophy can come to be seen as being a matter of calculation. Traditionally, utilitarian philosophers tend to favour this method. Bentham (1789) proposed a calculus to determine which act would bring about the greatest happiness for the greatest number of individuals. Moreover, in this view moral reasoning is an individual matter: I, as an individual, can calculate the greatest good for myself or for others.

The latter option takes us to engineering in a metaphorical and a literal sense. Utilitarians such as Bentham and Mill were concerned with society as a whole. They advocated social engineering. This concerns legislation as well as the concrete design of things. For instance, Bentham proposed the famous panopticon: a building which allowed the guards to watch the prisoners while the latter did not know if they were being watched. In this way, they could be better disciplined, as Foucault (1975) put it in his famous study.

More generally, moral philosophers working in this tradition seek to change society top-down. In this respect, they do not differ from Plato, who envisioned the ideal of the king-philosopher designing the perfect, well-ordered society. However, the model is not science as we know it today. Plato did not take to experimental science as a method to gain knowledge; instead, he held that gaining moral knowledge was a matter of theoria $(\theta \varepsilon \omega \rho i \alpha)$, which might be translated as insight or vision. Thus, it is not so much science that is a model here but theoretical science as opposed to experimental science. Science is seen as uncovering facts or truths rather than as a process of inquiry (as Popper and Dewey thought, see below). Moreover, utilitarian principles can be applied by everyone; they are more 'democratic' in this sense. Both Plato and traditional utilitarians shared the view that the moral life is a matter of gaining knowledge (indeed of theory) and that this knowledge should be applied to change society from above. Politics is a matter of attaining a vision of the Good and applying this knowledge to matters of state.

This interpretation of Plato as a top-down approach to politics seems in line with Popper's analysis in the first part of The Open Society and Its Enemies (1945), but he makes stronger claims. He argues that Plato's political programme is totalitarian (Popper 1945, pp. 92-93) and utilitarian-by which he means that 'the principle of collective utility is the ultimate ethical consideration' (Popper 1945, p. 146). Thus, we may compare Plato's collectivism and his view of the relation between knowledge and politics to collectivist versions of utilitarianism. Elsewhere Popper writes that for Plato, 'the criterion of morality is the interest of the state' and that therefore 'morality is nothing but political hygiene'. He accuses Plato of defending 'the collectivist, the tribal, the totalitarian theory of morality' (Popper 1945, p. 113). 
Although this reading of Plato may be too one-sided when it comes to the strong emphasis on collectivism and totalitarianism and to the relation between morality and politics (see for example Vlastos's reception of Plato $^{2}$ ), his political programme-or, if Vlastos is right, the political implications of his moral programme - can be identified as promoting a top-down approach to politics that appears to have collectivist and totalitarian tendencies. However, here I am not so much interested in finding out whether or not Plato held that view, but rather in how such an approach to morality and politics can be related to a view of how to attain knowledge. In so far as engineering is 'theoretical' science, it compares to the moral and political approach described above.

Finally, engineering as a (calculating, theoretical) science also promotes a certain attitude towards the unexpected and the uncertain. In this view, risk is something that can and should be calculated. A theory of risk is applied to get the world of contingency under human control. Similarly, moral philosophers who see morality as (theoretical) science try to create abstract rules and principles that control or stand above the contingencies and risks of everyday life. According to Popper, Plato's 'wise men' are too occupied with the problems of the superior world, they hold fast to 'the ordered and the measured' and have no time to 'look down at the affairs of men' (Popper 1945, p. 155). Whether or not this really was Plato's view, it is certainly a view that encourages an attitude to risk that centres on calculation and control.

To conclude this section: there are some features of engineering as (theoretical) science that help us to construct the outlines of an approach to morality and politics focussed on gaining theoretical knowledge, calculation, the individual, theory, topdown social engineering, and abstract, contingency-independent principles. Taking into account Popper's interpretation of Plato, we can add that this approach shows some similarities with collectivist versions of utilitarianism and is at least in danger of promoting totalitarianism. Of course this model of engineering, morality, and politics is an ideal-type. In practice, not all engineers, philosophers of (engineering) science, and moral philosophers that are sympathetic to this approach endorse all elements of this model or contribute to its moral and political implications.

\section{Morality as Engineering Practice and Experimental Science: Problem-Solving and Experimentation}

Let me now articulate an alternative understanding of morality by drawing on metaphors related to engineering as a practice and experimental science. I will show that this yields a more adequate description of, and better guide to, the moral life.

\footnotetext{
2 Vlastos argues in his Platonic Studies that Plato's goal was moral improvement, the improvement of the soul, rather than the interest of the state (Vlastos 1973/1981, p. 14) and that therefore Popper should have said that politics is moral hygiene rather than that morality is political hygiene (p. 15). Thus, the relation between the moral and the political in Plato is more complex than suggest by Popper and in the arguments presented above.
} 
Engineering as a practice puts less emphasis on knowledge as such but on problem solving, on getting things to work. In moral philosophy, there are a few traditions that follow a similar track. As McCarthy has argued, Wittgenstein understood philosophy as a problem-solving activity-perhaps because he was trained as an engineer (McCarthy 2007). Pragmatist philosophers such as Dewey share this conception of philosophy. Although Dewey modelled ethics on scientific inquiry (Dewey 1920) and could therefore agree with the phrase 'morality as science'-that is, as experimental science, he stressed the aspect of problemsolving: ethics is about solving practical problems. ${ }^{3}$ Of course there are differences. Whereas for Wittgenstein and his followers we should solve problems in our use of language in order to solve problems in our thinking (and perhaps in the world), Deweyan pragmatists are more directly concerned with practical problems of how we should live and how we should live together. But whatever the emphasis, the aim is to solve problems, not to gain knowledge or insight (theory) as such. If living together doesn't work, we should try to make it work by means of philosophical thinking and moral practices.

Moreover, this approach accepts contingency and accepts the risk that something can go wrong. In this respect, it has close affinities to the emphasis on inquiry and imaginative rehearsal in contemporary pragmatism (Fesmire 2003) and to Nussbaum's neo-Aristotelianism, which is critical of Plato's emphasis on control and instead promotes the acceptance of contingency and vulnerability (Nussbaum 1986). This outlook on risk and morality differs from many modern moral theories. Kant, Rawls, and contemporary consequentialists generally hold a top-down approach to morality (rules or principles applied to concrete 'cases') that is contingency-averse. For example, Rawls has argued that we should reason about the principles of a just society behind a veil of ignorance (Rawls 1971), removed from the real world. Against Rawls, Fesmire has argued that pragmatist ethics 'must begin where all genuine inquiry begins: in media res, with the tangles of lived experience'. For Dewey, moral deliberation 'is not disembodied cerebration deciding which action is derivable from ultimate principles, but is a form of engaged inquiry touched off by an uncertain situation' (Fesmire 2003, p. 28). ${ }^{4}$ And once we solve the problem, the situation remains uncertain or can become uncertain again.

I have no space here to offer a full critique of Rawls and other contemporary moral theories. Instead, let me elaborate the practical, experiential view of morality by using engineering metaphors. An engineering term for making something work well is performance. Applied to morality, this approach suggests that instead of aiming at knowing the good, we should try to do good. Good is not something that is out there and invites contemplation (the good) but something that needs to be designed and needs to work. The point is not to see the good (theoria, vision,

\footnotetext{
3 Here I am mainly inspired by that aspect of this thought (problem solving), less by his view that moral experimentation is a matter of confirmation. There have been further developments in 20th century philosophy of science which offer more interesting views, ranging from Popper's (1959) view that it is a matter of falsification to work by Kuhn, Feyerabend, and others.

4 Fesmire's view of Rawls might be too one-sided here. I have offered an alternative interpretation of Rawl's thought experiment, which demands rather than excludes the moral imagination Fesmire and Nussbaum promote (Coeckelbergh 2007a).
} 
perception) but to make good. Just as engineers try to solve technical problems by trying to make it work, we should try to solve practical moral problems and 'make the good work'. There is little point in seeing the good if our practices are not good or if our traditional norms or principles do not work. Instead of discerning eternal moral principles or putting forward a vision of the ideal society, we should shape good, starting from concrete problems and real people. This does not mean that principles are entirely obsolete or redundant. Engineering too requires knowledge of standards, rules, and procedures. But the main challenge in both engineering and moral philosophy is to imagine solutions when such rules, principles, and routines cannot be 'applied' - in other words: when there is a real problem. Then, when we do not know what to do, when we are in a situation of uncertainty, these principles are not very relevant. Moreover, even if we apply a principle, things might go wrong anyway. This is what Nussbaum called 'the fragility of goodness' (Nussbaum 1986). The moral life compares better to tragedy than to a computer programme (although even then there is still plenty of space for the tragic).

When we move from engineering and morality as theoretical science to engineering and morality as experimental science, we reverse the order in the relation between theory and experiment. Both conceptions of engineering and morality involve experimentation, but in the first case experiments are conducted in the service of the theory-in science to confirm or falsify (Popper 1959) the theory ${ }^{5}$ and in ethics to apply the theory-whereas in the second case the outcome is unknown and the experiment itself is what engineering and moral philosophy is about. It is a matter of trial and error rather than making a blueprint of the universe or of society. This kind of engineering and this kind of moral life relies on experience, learning, ${ }^{6}$ and improvisation. We do not know where we will end up, but we try out a tune (a music metaphor), try out some lines (a theatre metaphor). When the script is not clear or when there is no script, we have to improvise. This is how real life works. There is no master-author and we often do not know what to do.

This perspective also implies that neither engineering nor the moral life is a matter of individual thinking and individual action alone. If both have metaphorical connections with the performance arts, as I suggested, then they are fundamentally collaborative. Engineers work together to find solutions; making good is a collaborative matter too. The moral theatre play is not a monologue. The moral life is not a solo music play. Together we try to shape and design the good life.

This view is in tune with Dewey's view of morality as a social and imaginative enterprise that compares well to what happens in drama and music. Clarifying Dewey's conception of moral deliberation as dramatic rehearsal, Fesmire uses the metaphor of jazz improvisation: we always respond to what others do (Fesmire 2003).

A jazz musician [...] takes up the attitude of others by catching a cadence from the group's signals while anticipating the group's response to her own

\footnotetext{
5 Observations are theory-dependent or paradigm-dependent (Kuhn 1962).

${ }^{6}$ Consider also Dewey's view of learning and education. He held that all genuine education comes about through experience (Dewey 1938) and emphasized the ability to learn from experience (Dewey 1916, p. 49).
} 
signals. Drawing on the resources of tradition, memory, and long exercise, she plays into the past tone to discover the possibilities for future tones [...]. (Fesmire 2003, p. 94)

We do not start from a blueprint, but from the habits and institutions that are handed over to us from the past. As in the arts, there is no creation ex nihilo. Even the artist starting from a blank canvass does not start from nothing, but works within her connections with people and things, within her habits, within the tracks of personal history and societal history.

Such a view can accept that there is an important role for luck, contingency, and uncertainty. Instead of trying to gain full control in all cases, this kind of engineering and moral thinking tries to figure out what works within a given setting, situation, and context. Since the play depends on what all actors do, the play cannot be predicted. Moreover, if circumstances change, traditional engineering solutions and moral solutions may no longer work and we need to find a new solution.

Its emphasis on flexibility and adaptability renders this view of morality better suited to moral practice than the 'morality as theoretical science' variant. The world changes and our problems change. The 'morality as theoretical science' view, with its aim to uncover the eternal laws of the moral universe, is not as good in coping with these changes; it is too static. Instead, the 'morality as a practice' and 'morality as experimentation' view starts from concrete people facing concrete problems who need to find solutions to hard problems. If eternally valid moral principles solved these problems, we would be more than happy to welcome the philosopher-king and the social engineer-king. But in the real world we live in, this is a dream that is at best irrelevant and at worst dangerous.

\section{Open Source Politics}

As I suggested above when referring to Popper, the Platonic and scientific view of practical philosophy is vertical and top-down: we (philosophers or scientists who have seen the good and the truth) apply 'high', pure, heavenly principles and theory to the 'low', messy, dirty, earthly, practical world. This may result in a top-down politics with totalitarian tendencies. The 'morality as practice' view of the moral life, on the other hand, goes with a view of politics that is very different from the one that corresponds to a theoretical-scientific view: it suggests a more 'horizontal' and bottom-up view of politics. Let me further articulate this alternative view by using a term from software engineering.

A central advantage of the 'horizontal' view is that it is close to one of our best moral-political ideals: democracy. In its liberal-democratic version, the ideal prescribes what Popper (1945) called an 'open society'. History is not working towards an end-phase, as Hegel and Marx thought; societies are 'open' and should be non-totalitarian. In its participatory version, however, the ideal of democracy demands not only negative freedom (limits to state intervention in my personal life), but also participation: we-that is, all citizens-shape society. 
Now such a two-fold ideal of openness and participation can also be found in software engineering sub-cultures, in particular in the open source movement. Using open source as a metaphor, we can further fine-tune and develop our democratic ideal(s). In an open source culture, everyone has access to the code (the source) and can change it. It replaces a centralist model of software development, where there is a divide between the designers/producers, on the one hand, and the users and hackers, on the other hand. In the Platonic model, the philosopher-king writes the code. He is the author; the others are users of the applications. (A similar model can be found in creationist religion: God is the Author of the code of all that exists.) This is, literally, an authoritarian model.

Our 'democratic' societies may not be totalitarian or authoritarian, but they remain rather centralist. There is a gap between politicians and administrators (policy designers and producers), on the one hand, and citizens (policy consumers), on the other hand. Only the former have access to the code. There are a few 'hackers' who try to resist, but they do not achieve much. Representative democracy has become marketing, which seems unavoidable given the centralist model: marketing is only meaningful if there is a gap between producers and consumers, since only then the producers need to know what the consumers want.

A structural way to open up our societies, then, is to open up the political and moral code to everyone. In other words, we need real participation and involvement rather than representation. Now one could endorse a biological interpretation of the code metaphor, which would imply that our moral and political systems mutate and evolve (although with no end-point) whatever we do. This is an interpretation that promotes passivity. But the open source engineering interpretation of code understands openness as a possibility and invitation for our active involvement and (decentralised) steering. The decentralisation is achieved in analogy with open source engineering: there is a network of participants connected in a network. Consider also the wiki concept: authorship becomes less important; knowledge is the result of contributions from a network of contributors and the wiki entry is always open to editing. When it comes to decentralisation, the network metaphor is an attractive way both to voice the decentralisation ideal and to describe already existing structures and processes in contemporary society. We can imagine an open source society in which all citizens (have the opportunity to) contribute to writing and editing the codes of society.

Although the participatory version of democracy has been around for a while and seems difficult to realise, the open source metaphor provides a novel way of restating the ideal and to reflect on how to make it work in practice. For instance, using metaphors from web design, we can make a distinction between the practice of writing directly in 'HTML' (compares to more abstract ethics, using a technical language and perhaps reflecting on the basic principles and norms of our society) and the practice of using existing 'design software' in order to redesign our moral and political frameworks and public 'sites' (more popular discussions, using existing ethical tools and concepts, e.g. in applied ethics, in politics, and in the media). There are different kinds of moral 'dreamweavers', different languages, and different levels in the practice of normative reflection. And participation in politics 
and society does not require that everyone does all of that all the time. Important is that citizens have the opportunity to do so if they wish.

Let me further develop this point by re-connecting to the pragmatist tradition. The code need not be re-written all the time-let alone be revised as a whole. Most of the time norms are not contested and not problematic, and if we revise, we usually need to revise a small part of the code only. Moral design (as engineering design and art) is always responsive to its cultural and historical context. The code is not written from scratch; there is a moral and political tradition. The important point is open access. This means that our thinking remains open to innovation and that our moral and political practices remain open to change. Moreover, when we try to change (that is, improve) the code, we can use previous patterns and learn from others, but open source implies that there is room for experimentation and improvisation in the collective design of moral and political solutions. If we want our societies to be opened up and to remain open, we badly need such exercises of moral imagination and moral performance.

\section{Implications for Engineering and Society: A Response to Two Problems of Alienation}

In the discussion above, engineering metaphors were used to articulate a moral and political ideal. But what are the implications for engineering? The answer has already been partly provided: there are developments such as open source that point in the right direction. But we should also look beyond software and add grassroots initiatives such as Fab Lab: mass production is replaced by small-scale workshops where people design and produce their own artefacts by using computers and computer-controlled tools (Fab Lab started at MIT but has by now become a concept applied in many countries). Further reflection on these developments helps us to explore the implications of more 'open' models of morality and politics for engineering design. For this purpose, we must look into the relation between how things are produced and how humans live-in other words, we could benefit from considering a Marxist problem definition.

Usually engineering design takes place within the context of industrial mass production. But mass production is problematic in many ways. A famous objection to it has been offered by Marx. His theory of alienation states that the historical development from individual production and small workshops to large-scale industrial mass production has lead to misery and alienation. Whereas workers were first in control of their work and expressed their personality in the objects they designed and made, mass production creates distance between workers and objects and removes the possibility of self-realization. The craftsman becomes a labourer, who no longer enjoys life. As Marx puts it in his comments on James Mill (in the socalled Paris Notebooks): work is no longer a 'free manifestation of life' and 'I work in order to live' (Marx 1844/1932). Thus, there is a gap between design and production/labour.

Let me assume that this analysis is correct. How relevant is it for contemporary society? For whom is alienation a problem? One may object that most people do not 
work in manufacturing and that therefore Marx did not identify the most urgent or most important problem. Therefore, let me go beyond Marx and define a slightly different alienation problem that is more pressing today: consumer alienation. In contemporary consumer society, there is not only a gap between design and labour; there is also a gap between on the one hand, design and production and, on the other hand, consumption. Thus, there are at least two alienation problems here; alienation is also a problem for consumers - which we all are. Therefore, a further discussion of the problem is relevant to all of us, not only to engineers or workers.

Let me elaborate my argument. Design and production of consumption goods are far removed from our lives. They are made in processes over which we have had no control and receive little information. Others with whom I have no connection determine what products are made. The objects we use and the food we eat are initially completely alien to what we are. Of course we then use and consume them; we try to make them 'our own' and thereby mitigate the initial alienation. But this only succeeds to some extent. The food we eat and the objects we use retain an alien dimension. In practices such as working with computers and eating industrially processed food (which has become a quasi-artefact), we experience this existential alienation when the computer programme does not function well or when the food we eat risks damaging our health. Then we start asking questions about the design and production of these artefacts and quasi-artefacts. These are the moments when consumer alienation peaks: we feel helpless in the face of technological risk, which is created by design and production processes that are remote from us and our lives. Of course we are not always or totally alienated. What we do with our computers and what we eat changes who and what we are. In a sense, we are the food we eat (as the common saying has it) and we are becoming the computer programmes we use. We adapt our thinking and our lives to them. To the extent that we become increasingly dependent on the artefacts we use and consume, to the extent that we merge with them, we become cyborgs, perhaps. But we remain half-alienated cyborgs, unable to accomplish full integration since the link with design and production is missing.

For engineering, I infer, these two related forms of alienation imply that the engineer who designs a product has no control over its production and use, and the user is far removed from the design stage and the production stage. This leaves the engineer in a position of a double or triple alienation: as a designer, (s)he is removed from production and use, and as a consumer (of other products) (s)he is removed from the design and production of those products.

In line with the experiential view presented above, one may object that this analysis is inadequate since it is based on a Marxist problem definition and Marxism doesn't 'work'. For example, Popper would view Marxism as falsified. However, this is a superficial criticism of Marxism, since it does not address the remaining alienation problems(s). It is true that communist systems, using an ideology inspired by Marx, have generally failed (although perhaps not always or not mainly for reasons having to do with Marxist theory). But we should not confuse the analysis of the problem with the solution. We can think of non-totalitarian ways of overcoming alienation. Moreover, as I said above my analysis goes beyond Marx in identifying a distinct problem of alienation. Let me distinguish between three possible solutions. 
One is to return to pre-industrial, low-tech production of simple commodities by craftsmen and by ourselves. For instance, at the end of the nineteenth century the designer and socialist William Morris initiated what is now known as the Arts and Crafts movement. He proposed to revive the concept of medieval guilds, started up a crafts community, and wrote a utopian novel News from Nowhere (1890) in which he envisioned a future society that knows no private property and is basically agrarian. For most of us, the agrarian model is not a serious option: we are too much addicted to high-tech consumer goods.

Then there is the Communist (or State Socialist) option chosen by many states in the twentieth century: abolish private property and make production a collective matter, but continue industrial development. In practice, this has meant that the state takes control over production. However, contrary to communist ideology this has not solved the alienation problem, since the system of mass production has been retained and therefore the distance between designer, producer, and user. Politically and socially speaking, perhaps alienation has even increased given the large gap between individual and state (as the owner of the means of production) - a problem that has only been mitigated at the cost of inducing strong nationalist ideologies and authoritarianism. After all, both the Arts and Crafts utopian option and the State Socialist 'scientific' option rest on a Platonic, top-down approach to truth, morality, and politics: 'I have a vision. Follow me.'

A better solution, therefore, is to turn to modes of production that remain hightech and do not-in principle at least-abolish private property and other 'bourgeois' institutions, but change society 'from within' by setting up noncommercial, radically de-centralised modes of production. Open source and Fab Lab are ways of engineering that are not morally or politically neutral; instead, according to this analysis they can be understood as novel, non-collectivist and technology-friendly solutions to the alienation problem that, by changing the mode of production and by providing a model for societal organisation, nurture and shape an 'open' morality and an open society.

If successful, this change will require no less than the re-invention of engineering as a profession, in ways that are hard to foresee now. We are used to see engineers as having a specialist role within commercial or academic top-down institutional settings, as making a partial contribution to either design, research, or production. We are used to a society built around mass production. We are used to be passive users of commodities, to minimal political participation, and to top-down morality. But these developments and these reflections invite us to imagine how to make things work better, without any guaranties, promises or certainties-without the guaranties, promises or certainties of utopian thinking or old-fashioned theoretical science.

Let me strengthen this last point by responding to the following related objections. With regard to politics and knowledge, one may object that open source science may deteriorate into assertions that are unsupported by evidence and that open source politics may introduce undesirable political solutions. And with regard to engineering design and production, one might object that there is a problem about quality. Would workshops like Fab-lab make goods cheaper, more available, more standard in quality, more sustainable, etc.? These objections are related: they worry 
that too much openness might result in the absence of truth and good. Let me respond to this concern.

First, experimental science and experimental, open politics does indeed incur the risk that some 'products' of knowledge are 'trash' and that some political solutions do not work. It is to be expected that the music of open source politics will sometimes create noise and that some plays in the theatre of science will lack beauty. I believe there are two responses to this problem.

A first possible response is to introduce a general framework of rules and principles within which there is openness and freedom but which limits this space of experimental freedom. This is, in fact, what we do in democratic societies: we try to rule out movements that undermine the democratic system itself. It is also what we do in science by demanding that work meets methodological standards. Thus, one may agree on some general rules and principles that rule out some experiments.

Is this a concession to the 'top-down' approach? This depends on the motivation and the status of these rules. It is a concession if it is motivated by a desire for full epistemic, political, and moral security. It is also a concession if these rules are seen as a script set in stone, eternally and generally valid and not to be changed. But if it is admitted that even such 'constitutional' rules and principles cannot guarantee full security and if it is conceded that even such rules and principles might be up to revision if our systems of knowledge production and our societies were to change radically and a situation of deep uncertainty arises, then such an approach can still be identified as experiential and bottom-up. ${ }^{7}$

A second response is that open source systems have a built-in capacity for continuous self-regulation and self-correction. A wiki-type knowledge generation system might have some 'top-down' rules that outline a framework, but most of the corrections are done by the participants, as in the application Wikipedia. As I said above, a wiki is always open to editing. Peer-review in contemporary academia has a similar function. And based on this model, one might conceive of a wiki-politics with (more) built-in correction processes that allow the system to (better) selfcorrect itself. A society may need some 'framework' rules or 'constitutional' rules to facilitate this, but if and once facilitated, the mechanism itself works without continuous, detailed, and top-down 'editorial' intervention.

Second, with regard to the design, production, and consumption of goods one might imagine similar framework rules and self-correcting mechanisms. For example, if the designer and the consumer are one and the same person (or are closely connected), then it is unlikely that something will be produced that is of poor quality. Why would anyone self-produce a bad product? But another worry concerns scale, cost, and availability. It is true that the current top-down systems (the free market ones and to some extent the centralist ones) have been very good in making goods cheaper, more available, more standard, has benefited from efficiencies of scale etcetera. However, the result has been that quality and especially sustainability is often low: life cycles get very short. Similarly, it is relatively 'cheap' to have one centralist policy, but this has

\footnotetext{
7 Note that this position is similar to the one I defended in Coeckelbergh (2007b) — there is no necessary opposition between principles and imagination-but my position is now made clearer and perhaps goes further in allowing more 'openness' when it comes to 'fundamental' principles.
} 
not always contributed to the quality of the policy. I grant that small scale production is less efficient, of course, which might make these goods more expensive and more local, but given the alienation problem and the risks associated with large-scale production of artefacts and food, many consumers may pay the price if the quality and sustainability is high. For example, people are increasingly willing to pay for biological and local food.

In the end, there is no hard guarantee that the products produced in smaller workshops or small farms are of better quality-as there is no guarantee that they are of good quality in the current system. However, the type of 'quality control' differs. In the 'old' system it is mainly a top-down quality control, based on rules and procedures imposed by management. The problem is then how to get feedback from consumers (which they get, but it is always 'after the fact' evaluation). This compares to the problem in top-down politics that there is a gap between politicians and citizens: politicians feel cut off from their citizens and vice versa. In the alternative system, quality control is bottom-up by producers-consumers (anticipatory, on beforehand) and by consumers. The politics based on this model is a participatory democracy. Just as there is participation in the product design phase, there is participation in the policy design phase.

The latter system can cope better with the fact that there is no hard guarantee, since it does not seek it in the first place but understands itself in terms of experimentation. Similarly, a political system may understand itself in terms of experimentation. This view is in line with Dewey's view of morality: he argued that although we seek full moral security by means of principles and 'foundations', there is no guarantee that a solution for one problem at a given time will work at all (we have to go by trial and error) and that it will work for the next problem in the future. We have to work with 'soft' foundations and within shaky frameworks.

\section{Conclusion}

Let me draw some conclusions. I have articulated two views of moral and political thinking by relying on two perspectives on engineering. One is engineering as theoretical science, which is a vertical approach that aims at seeing the truth (and then perhaps tries to confirm or falsify its theory by means of experiments). Its analogy in moral philosophy is morality as theoretical science, which attempts to see the good and then tries to apply that theory and vision to concrete problems in order to gain full control. Rules are made top-down to solve practical problems and diminish risk and uncertainty. The other view is engineering as a practice, as a process of experiment and inquiry, which starts from such concrete problems and which tries to solve problems (know-how) rather than gain knowledge (know something). In order to do this, it relies on experimentation and improvisation and accepts that things can go wrong. Rather than relying on rules or methodologies alone, it has self-regulating mechanisms and grants that even our 'constitutional' rules and principles might need revision when the situation becomes uncertain. In analogy to this understanding of engineering and (experimental) science, I have articulated the outlines of a practical philosophy that aims at solving problems, at 
doing good, and at shaping good by experimenting, improvising, and self-correcting in the light of contingency and uncertainty.

To these views of the moral life I connected two different views of politics and political philosophy. One approach is vertical and top-down, aiming at social engineering in the sense of designing a perfect society from scratch, starting from theoretical principles. This approach is typical for totalitarian regimes, but is also present in current democracies in so far as they rely on top-down approaches and general rules alone to solve problems. The other is also a kind of social engineering, but starts from given structures, is experimental, works by trial and error, has no final end-point in view, is decentralised, participatory (horizontal), self-correcting, and welcomes contributions from a variety of moral languages. It shares this spirit with developments such as open source, wiki, and Fab Lab, which I interpreted as pointing the way towards a better solution to the two alienation problems discussed than the ones offered by utopian and statist (versions of) socialism. This approach will benefit designers, producers, and consumers. (Note that if the alienation problems can be solved, these roles converge and we might have to invent new names for what we do. Here I have drawn on our information technology practices, so central in contemporary lives, to talk about these roles in a different way.)

I conclude that although both interpretations of 'engineering good' are part of a comprehensive picture of our moral possibilities and cannot solve all our problems, given their adaptability to change, their proximity to the best political ideal we have, and their ability to cope with the alienation problems in a novel and better way than its alternatives, experimental problem-solving morality and open source politics are more adequate ways not only to understand and guide the moral life but also to reshape engineering and society.

Open Access This article is distributed under the terms of the Creative Commons Attribution Noncommercial License which permits any noncommercial use, distribution, and reproduction in any medium, provided the original author(s) and source are credited.

\section{References}

Bentham, J. (1789). In J. H. Burns \& H. L. A. Hart (Eds.), An introduction to the principles of morals and legislation. London: The Athlone Press, 1970.

Coeckelbergh, M. (2007a). Principles or imagination? Two approaches to global justice. Journal of Global Ethics, 3(2), 203-221.

Coeckelbergh, M. (2007b). Imagination and principles: An essay on the role of imagination in moral reasoning. Basingstoke/New York: Palgrave Macmillan.

Dewey, J. (1916). Democracy and education. In J. A. Boydston (Ed.), J. Dewey, The middle works 18991924 (Vol. 9). Carbondale: Southern Illinois University Press, 1980.

Dewey, J. (1920). Reconstruction in philosophy. In J. A. Boydston (Ed.), J. Dewey, The middle works 1899-1924 (Vol. 12). Carbondale: Southern Illinois University Press, 1982.

Dewey, J. (1938). Experience and education. In J. A. Boydston (Ed.), The later works, 1925-1953 (Vol. 13). Carbondale: Southern Illinois University Press, 1988.

Fesmire, S. (2003). John Dewey and moral imagination. Bloomington, IN: Indiana University Press.

Foucault, M. (1975). Discipline and punish: The birth of the prison. New York: Random House.

Johnson, M. (1993). Moral imagination: Implications of cognitive science for ethics. Chicago: University of Chicago Press.

Kuhn, T. (1962). The structure of scientific revolutions. Chicago: University of Chicago Press. 
Lakoff, G., \& Johnson, M. (1980). Metaphors we live by. Chicago: University of Chicago Press.

Marx, K. (1844/1932) Comments on James Mill. In K. Marx \& F. Engels (Eds.), Collected works (trans: C. Dutt). London: Lawrence and Wishart, 1975.

McCarthy, N. (2007, November). A world of things, not facts. Paper presented at the Workshop on Philosophy and Engineering, Delft University of Technology.

Morris, W. (1890) News from nowhere and other writings. London: Penguin, 1993.

Nussbaum, M. C. (1986). The Fragility of goodness: Luck and ethics in Greek tragedy and philosophy. New York: Cambridge University Press.

Popper, K. R. (1945). The open society and its enemies (Vol. 1: The spell of Plato). London: Routledge, 2002.

Popper, K. R. (1959). The logic of scientific discovery. London: Hutchinson.

Rawls, J. (1971). A theory of justice. Cambridge, MA: Belknap Press of Harvard University Press.

Verbeek, P. P. (2005). What things do. Pennsylvania: Pennsylvania State University Press.

Vlastos, G. (1973/1981). Platonic studies (2nd ed.). Princeton, NJ: Princeton University Press. 